\title{
Where did equity in education improve over the past decade?
}

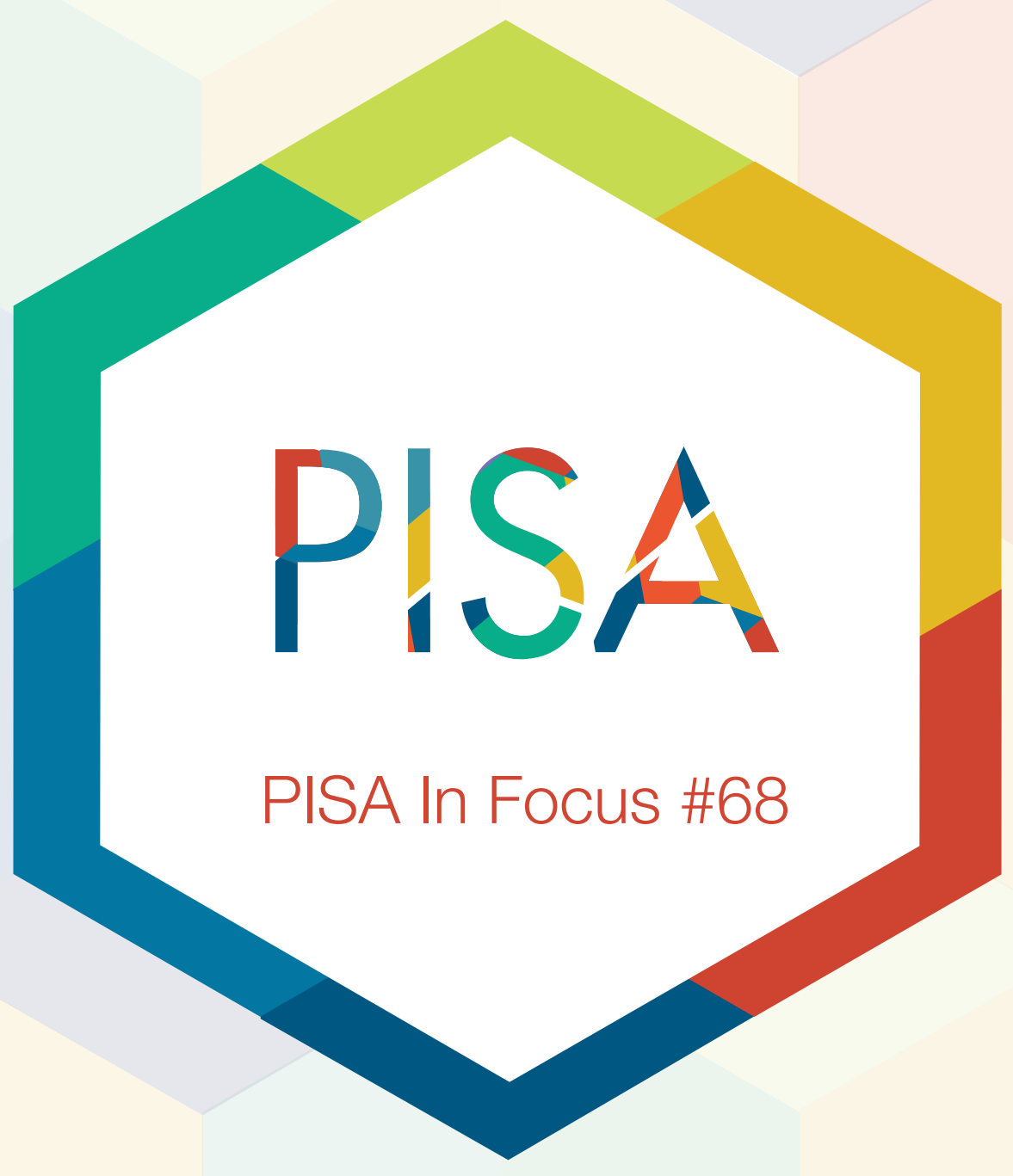




\section{Where did equity in education improve over the past decade?}

- Between 2006 and 2015, equity in education, measured by how much variation in performance is explained by students' socio-economic status, improved in 11 PISAparticipating countries and economies, and on average across all OECD countries.

- The United States stands out as the country where, between 2006 and 2015, the impact of a student's socio-economic status on his or her performance in school weakened the most, and where the likelihood that disadvantaged students perform at high levels increased the most.

- No country or economy improved both performance in science and equity between 2006 and 2015, but mean achievement remained stable in nine countries where socio-economic status became a weaker determinant of student performance.

The persistence of social inequities in education - the fact that children of wealthy and highly educated parents tend to do better in school than children from less privileged families - is often seen as a difficult-to-reverse feature of education systems. Yet countries across the world share the goal of minimising any adverse impact of students' socio-economic status on their performance in school. PISA shows that, rather than assuming that inequality of opportunity is set in stone, school systems can become more equitable over a relatively short time.

The level of equity in an education system can change in the span of a decade.

Equity in education is promoted by removing obstacles to the development of talent that stem from economic and social circumstances over which individual students have no control, including unequal access to educational resources in their family and school environments. One of the ways PISA examines equity is by looking at how well a student's socio-economic status predicts his or her performance (what PISA calls the strength of the socio-economic gradient). Recent trends in equity are best analysed by comparing the evolution of this indicator between PISA 2006 and PISA 2015, two rounds of PISA when science was the focus of the assessment.

Over the past decade, equity improved modestly in many PISA-participating countries and economies. In 2006, on average across OECD countries, $14 \%$ of the variation in students' science performance could be explained by students' socio-economic status; by $2015,13 \%$ of the variation in performance could be so explained. But in Bulgaria, Chile, Thailand and the United States, the socio-economic gradient weakened by between 6 and 7 percentage points, while in Brazil, Denmark, Germany, Iceland, Mexico, Montenegro and Slovenia it weakened by between 2 and 6 percentage points. Progress towards greater equity is even more commendable as many of these countries saw rising income inequality over the same period. And four of these countries - Bulgaria, Chile, Germany and the United States - moved from being below the OECD average in equity in 2006 to aligning with the OECD average in 2015. 
Change in the percentage of the variation in science performance explained by socioeconomic status

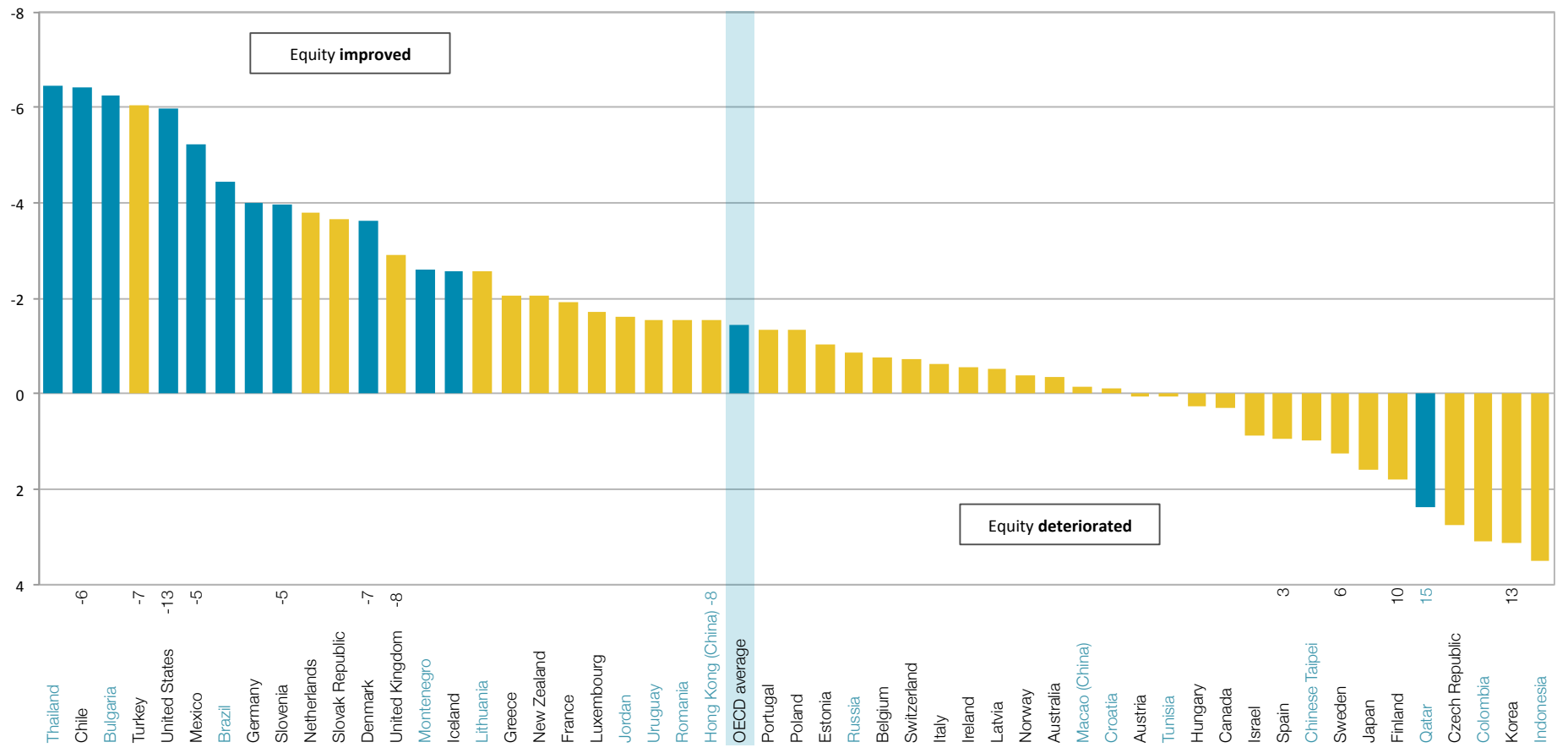

Notes: Statistically significant differences are shown in blue.

Statistically significant changes between 2006 and 2015 in the score-point difference associated with a one-unit increase on the PISA index of economic, social and cultural status are shown next to the country/economy name.

Only countries and economies that participated in both PISA 2006 and PISA 2015 are shown.

Countries and economies are ranked in descending order of the weakening of the socio-economic gradient (how well socio-economic status predicts performance) between 2006 and 2015.

Source: OECD, PISA 2015 Database, Table I.6.17.

Trends in equity are also reflected in changes in the average impact of socio-economic status on performance. Over the past decade, the average difference in performance observed between students from different socioeconomic groups decreased by 13 score points in the United States, and by between 5 and 8 score points in Chile, Denmark, Hong-Kong (China), Mexico, Slovenia, Turkey and the United Kingdom.

Was progress in equity driven by improvements in performance among disadvantaged students? Trends in student "resiliency" suggest that, in many countries, this was the case. Resilient students are those from disadvantaged backgrounds who beat the odds against them and perform at high levels when compared with students of the same socio-economic status from around the world. Between 2006 and 2015, the percentage of resilient students increased by more 12 percentage points in the United States, while it increased by between 4 and 9 points in Bulgaria, Denmark, Germany and Slovenia. School systems in which the proportion of resilient students grew over time are those where the chances for disadvantaged students to become high achievers improved. 


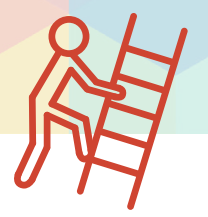

\section{Greater equity need not come at the expense of performance.}

PISA consistently finds that high performance and greater equity in education are not mutually exclusive. Given this, success in education can be defined as a combination of high levels of achievement and high levels of equity. Indeed, among the 24 education systems with above-average performance in science in PISA 2015, the strength of the relationship between performance and socio-economic status was weaker than the OECD average in 10 systems.

Policy reform to foster equity in education opportunities and outcomes need not be a liability to mean achievement. PISA shows that, between 2006 and 2015, the strength of socio-economic gradient weakened in nine countries that also managed to maintain their average performance in science: Brazil, Bulgaria, Chile, Denmark, Germany, Montenegro, Slovenia, Thailand and the United States. In these countries, students' socio-economic status became a less reliable predictor of performance while average achievement remained stable.

\section{Trends in equity and science performance between 2006 and 2015}

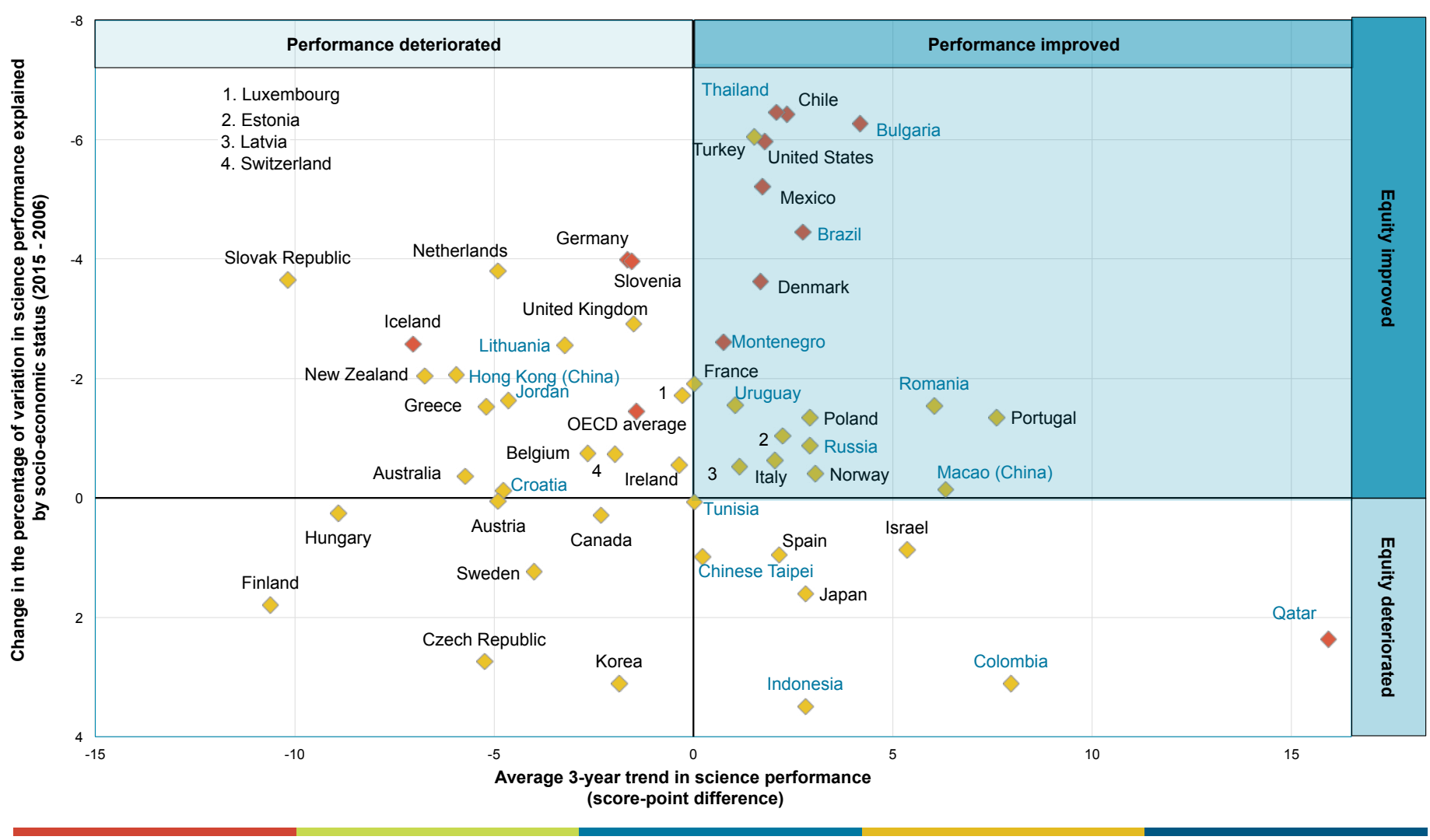

Notes: Only countries and economies with available data are shown. Changes in equity between 2006 and 2015 that are statistically significant are indicated in red.

The average three-year trend is the average rate of change, per three-year period, between the earliest available measurement in PISA and PISA 2015. For countries and economies with more than one available measurement, the average three-year trend is calculated with a linear regression model. 


\section{How PISA measures socio-economic status}

In PISA, socio-economic status is estimated by the PISA index of economic, social and cultural status (ESCS), which combines student responses to questions about their parents' occupations and educational attainment and about the material and educational resources available in students' homes, such as the number of books. The ESCS index makes it possible to draw comparisons between students and schools with different socio-economic profiles. Students are considered socio-economically advantaged if they are among the $25 \%$ of students with the highest values on the ESCS index in their country or economy; students are classified as socio-economically disadvantaged if their values on the ESCS index are among the bottom 25\% within their country or economy.

Education policies that can foster improvements in equity and performance include targeting additional resources to schools with a high concentration of low-performing and disadvantaged students to keep them from falling behind; and ensuring that high and consistent teaching and learning standards are applied across all classrooms. Broader social policies that help to ensure that the early life experiences of advantaged and disadvantaged children are not too different can also promote both equity and high performance when these children enter formal education.

\section{The bottom line:}

Equity in education is also a matter of design and, as such, should become a core objective of any strategy to improve an education system. As socio-economic status becomes a weaker determinant of student performance over time, student resiliency tends to increase, and the proportion of low-performing students - who often come from disadvantaged backgrounds - tends to shrink. This suggests that policies aimed at helping disadvantaged students thrive academically should go hand-in-hand with policies that target low achievers. 
Contact: Carlos González-Sancho (carlos.gonzalez-sancho@oecd.org)

Reference: OECD (2016), PISA 2015 Results (Volume l): Excellence and Equity in Education, PISA, OECD Publishing, Paris, http://dx.doi.org/10.1787/9789264266490-en.

\author{
Visit \\ www.pisa.oecd.org \\ www.oecd.org/pisa/infocus \\ Adult Skills in Focus \\ Education Indicators in Focus \\ Teaching in Focus
}

Discover PISA 2015 results by country: www.compareyourcountry.org/pisa

Coming next month What kinds of careers in science do 15-year-olds expect for themselves?

This paper is published under the responsibility of the Secretary-General of the OECD. The opinions expressed and the arguments employed herein do not necessarily reflect the official views of OECD member countries.

This document and any map included herein are without prejudice to the status of or sovereignty over any territory, to the delimitation of international frontiers and boundaries and to the name of any territory, city or area.

The statistical data for Israel are supplied by and under the responsibility of the relevant Israeli authorities. The use of such data by the OECD is without prejudice to the status of the Golan Heights, East Jerusalem and Israeli settlements in the West Bank under the terms of international law

This work is available under the Creative Commons Attribution-NonCommercial-ShareAlike 3.0 IGO (CC BY-NC-SA 3.0 IGO). For specific information regarding the scope and terms of the licence as well as possible commercial use of this work or the use of PISA data please consult Terms and Conditions on www.oecd.org. 